\title{
IMPEACHMENT E REPRESENTATIVIDADE DEMOCRÁTICA: O PAPEL DOS SUPLENTES DE SENADOR
}

\begin{tabular}{|c|c|}
\hline & Santos \\
\hline Sombra ${ }^{1}$ & \\
\hline Suzane & Scandelari \\
\hline $\operatorname{Raupp}^{2}$ & \\
\hline
\end{tabular}

\begin{abstract}
Resumo
O presente artigo tem por objetivo verificar em que medida a atuação dos suplentes de senador é consentânea com os conceitos de soberania, democracia e representatividade - haja vista não serem investidos no cargo pelo voto popular direto. O primeiro tópico trará as noções iniciais sobre o processo de impeachment, desde suas origens históricas até a forma atual do instituto no ordenamento jurídico brasileiro, delineando a atuação do Senado Federal no julgamento do processo. O segundo traçará os conceitos de soberania, representatividade e democracia e a relação existente entre eles, especialmente mediante a análise das obras de Nadia Urbinati, buscando esclarecer de que forma se dá a escolha e a responsabilização dos representantes políticos eleitos. O terceiro tópico, por fim, abordará as características do cargo do suplente, principalmente mediante a análise da legislação pátria, com vistas a entender seu papel no processo de impeachment, especialmente diante dos conceitos trabalhados nos tópicos anteriores.
\end{abstract}

Palavras-chave: Impeachment; Suplentes de Senador; Democracia representativa; Direito Constitucional.

\section{INTRODUÇÃO}

Em $1^{\circ}$ de setembro de 1992, Barbosa Lima Sobrinho, presidente da Associação Brasileira de Imprensa, e Marcello Lavenère Machado, então presidente da Ordem dos Advogados do Brasil, entregam ao presidente da Câmara dos Deputados, Ibsen Pinheiro, o pedido de impeachment do Presidente Fernando Collor de Mello pela suposta prática de crimes de responsabilidade. Vinte e nove dias depois, por 441 votos a favor, a Câmara dos Deputados autoriza a abertura do processo. Passados vinte e três anos, o impeachment volta a ser

\footnotetext{
${ }^{1}$ Professor de Direito Privado e Doutorando na Universidade de Brasília-UnB, Mestre em Direito Privado pela Pontifícia Universidade Católica de São Paulo-PUC/SP. E-mail: thiagoluissombra@gmail.com
} 
manchete de jornais e revistas e a intrigar a população.

O interesse pelo assunto é proporcional à falta de trabalhos a respeito no Brasil. A obra de Paulo Brossard, "O impeachment”, escrita em 1965 e reeditada em 1992, continua a ser o estudo mais completo sobre o assunto. Isto se deve, em parte, à sua pouca aplicação no direito brasileiro. Em mais de 120 anos de República, o instituto foi efetivamente usado contra o Presidente uma única vez, em 1992.

Atualmente, dos 81 senadores em exercício, 14 são suplentes. Isso corresponde a, aproximadamente, um quinto da Casa. Destes, nenhum foi diretamente eleito. Isso significa que mais de $15 \%$ dos senadores tomam decisões sem ter recebido um único voto para isso.

Esta questão tem sido objeto de discussão e de tentativas de mudança. Seis propostas de emenda à Constituição estão atualmente em trâmite na Câmara dos Deputados e no Senado Federal, todas voltadas à alteração da forma de provimento do cargo de suplente ${ }^{3}$. Em 2 de julho de 2013, a Presidenta Dilma Rousseff enviou uma mensagem ao Congresso Nacional propondo a realização de um plebiscito sobre a reforma política. Um dos pontos sugeridos era em relação à continuidade ou não da suplência no Senado (QUERO, 2013).

Diante disso, o presente trabalho visa analisar o papel do suplente de senador para participar do julgamento político do Presidente da República, tendo em vista não ter sido diretamente eleito para assumir o cargo. Dessa forma, buscar-se-á estudar as teorias de representação existentes e relacioná-las à questão do suplente, a fim de verificar se a existência do cargo se harmoniza, de fato, com o conceito de representação e democracia.

O primeiro tópico tratará do processo de impeachment, partindo de suas origens históricas, especialmente relacionadas ao procedimento na Inglaterra e nos Estados Unidos, e traçando as modificações ocorridas ao longo das Constituições brasileiras. O segundo tópico compreenderá a análise da ideia de soberania, democracia e representação, especialmente a partir da obra de Nadia Urbinati sobre democracia procedimental e democracia representativa, trabalhando especialmente os processos de escolha dos representantes e de prestação de contas (accountability). O terceiro tópico abordará o instituto da suplência senatorial, sua presença no ordenamento jurídico brasileiro e os critérios para a investidura no cargo. Será especialmente tratada a relação da suplência com o conceito de democracia representativa trabalhado no tópico anterior, a fim de responder à questão relativa à representatividade do suplente.

Ao final se demonstrará a inexistência dos requisitos necessários à representatividade

\footnotetext{
${ }^{2}$ Bacharel em Direito pela Universidade de Brasília. E-mail: suzi.scandelari@gmail.com
} 
democrática no caso dos suplentes de senador na medida em que, além de não serem investidos no cargo mediante eleição direta, não se submetem ao processo de prestação de contas.

\section{EVOLUÇÃO HISTÓRICA DO IMPEACHMENT}

\section{O impeachment nas constituições brasileiras}

A primeira Constituição brasileira, a Constituição do Império de 1824, já admitia o processo de impeachment, embora sua forma se assemelhasse à forma monárquica de responsabilidade dos ministros de Estado existente na Inglaterra. Em linhas gerais, a pessoa do imperador era, nos termos do artigo 99 da Constituição do Império, "inviolavel, e Sagrada: Elle não está sujeito a responsabilidade alguma" (BRASIL, 1824), mas seus secretários, ministros e conselheiros respondiam pelos crimes cometidos.

As denúncias poderiam ser feitas por qualquer cidadão, e este direito prescrevia em três anos; aos parlamentares era facultado apresentar a denúncia em até oito anos, período de duas legislaturas, conforme estabelecia o artigo $8^{\circ}$ da lei de 1827. O imperador, por sua vez, tinha o poder de indultar ou comutar as penas aplicadas pelo Senado (BROSSARD, 1992, p. 38).

Com a proclamação da República, a revogação da constituição de 1824 e a implantação do sistema presidencialista de governo, o modelo monárquico de responsabilização política perdeu espaço, uma vez que a pessoa do Presidente, diferente do imperador, era legalmente responsável por seus atos. O modelo de responsabilização adotado pela constituição de 1891 inspirou-se claramente no modelo norte-americano, mantendo, contudo, as características processuais da constituição de 1824 e da lei de 1827.

A mudança mais substancial foi em relação à natureza do instituto, que deixou de ser criminal. Isso porque, no modelo republicano, o processo de impeachment tem natureza política, embora as faltas possam ter "colorido e repercussões penais" (artigo $2^{\circ}$ do Decreto $\mathrm{n}^{\mathrm{o}}$ 30, de 8 de janeiro de 1892) (BROSSARD, 1992, p. 44).

$\mathrm{O}$ artigo 54 da primeira Constituição republicana apresenta rol taxativo de crimes passíveis de impeachment, e seu $\S 1^{\circ}$ impõe a definição desses crimes por lei especial, retirando, em parte, a discricionariedade do Congresso e limitando a aplicação do instituto (BRASIL, 1891; BROSSARD, 1992, p. 44-52). Cabia à Câmara dos Deputados declarar a procedência ou improcedência da acusação contra o Presidente da República; o julgamento era

\footnotetext{
${ }^{3}$ PEC no 376/2009 (BRASIL, 2009), no 141/2012 (BRASIL, 2012), no 379/2014 (BRASIL, 2014a), $n^{\text {o }}$ 39/2014 (BRASIL, 2014b), nº 48/2014 (BRASIL, 2014c) e n 18/2015 (BRASIL, 2015).
} 
de competência privativa do Senado Federal (Decreto nº 30/1892).

A Constituição de 1934 repetiu os preceitos da carta anterior, especialmente quanto à natureza e aos tipos de crimes de responsabilidade, inovando, contudo, em relação ao procedimento de impedimento. O julgamento do Presidente da República, nos crimes comuns, cabia ao Supremo Tribunal Federal e, nos crimes de responsabilidade, a um Tribunal Especial, reunido para este fim, composto de nove juízes, escolhidos por sorteio após decretada a acusação: três ministros do Supremo Tribunal Federal, três membros do Senado Federal e três membros da Câmara dos Deputados, sendo presidida pelo presidente do Supremo (BRASIL, 1934).

Oferecida a denúncia ao presidente do STF, este convocaria uma Junta Especial de Investigação, composta de um ministro daquele tribunal, um deputado e um senador. Como na constituição anterior, o Tribunal só poderia aplicar a pena de perda do cargo e inabilitação por até cinco anos para o exercício de qualquer função pública, sem prejuízo das ações civis e penais cabíveis (BRASIL, 1934).

A Constituição de 1937 reduziu ligeiramente o rol de crimes de responsabilidade, mantendo os que atentassem contra: a existência da União, a Constituição, o livre exercício dos Poderes políticos, a probidade administrativa e a guarda e emprego dos dinheiros público e a execução das decisões judiciárias. A competência para declarar, por dois terços dos votos de seus membros, a procedência da acusação cabia à Câmara dos Deputados, cabendo o processo e o julgamento ao Conselho Federal (BRASIL, 1937).

As mudanças trazidas pela Constituição seguinte, de 1946, diziam respeito à ampliação do rol de crimes, voltando a equiparar-se ao de 1934, e ao quórum para declaração da acusação pela Câmara: enquanto o texto constitucional de 1937 exigia o voto favorável de dois terços dos membros, o de 1946 exigia apenas a anuência da maioria absoluta na Câmara. Declarada a procedência da denúncia, o Presidente ficaria suspenso de suas funções. O presidente do Supremo Tribunal Federal era encarregado de presidir o julgamento no Senado (BRASIL, 1946).

Poucas alterações sofreu a Constituição seguinte: a de 1967 voltava a exigir o voto favorável de dois terços dos membros da Câmara dos Deputados para declarar a procedência da acusação, e dois terços dos votos favoráveis dos membros do Senado para proferir sentença condenatória. A alteração mais significativa foi em relação à duração do processo: o artigo 85, $\S 2^{\circ}$, estabelecia que "decorrido o prazo de sessenta dias, se o julgamento não estiver concluído, o processo será arquivado" (BRASIL, 1967). 


\section{O processo de impeachment hoje: a constituição de 1988}

O texto constitucional vigente observou, de modo geral, o modelo instituído pela Constituição de 1891, exceto pelo seguinte: a Câmara não mais declara procedente ou improcedente a acusação, limitando-se a autorizar a instauração do processo pelo Senado. Instaurado o processo, o Presidente fica afastado do cargo e o Vice-Presidente o substitui. Decorridos cento e oitenta dias, caso não seja proferida sentença definitiva, o acusado retorna ao exercício, mas o processo continua. Caso condenado, perde o cargo e torna-se inelegível pelo prazo de oito anos, e não cinco, como nas Constituições anteriores.

Além disso, o artigo $23, \S \S 1^{\circ}$ e $2^{\circ}$, da Lei $n^{\circ} 1.079 / 50$, que dispõe sobre a aprovação do parecer e a decretação da acusação, deve ser lido à luz do artigo 51, inciso I, da Constituição de 1988, que exige o voto de dois terços dos membros da Câmara para autorizar a instauração de processo contra o Presidente e o Vice-Presidente da República e os Ministros de Estado, uma vez que o artigo 81 daquela lei, que exigia apenas o voto da maioria absoluta dos membros da Câmara para "decretar a acusação", não foi recepcionado.

$\mathrm{O} \S 5^{\circ}$ do artigo 23 tampouco foi recepcionado pela Constituição de 1988: autorizada a instauração do processo pela Câmara, não fica o acusado suspenso do exercício de suas funções. O artigo 86, $\S 1^{\circ}$, inciso II, sujeita a suspensão do Presidente, nos crimes de responsabilidade, à instauração do processo pelo Senado Federal, não antes disso.

\section{O papel do senado federal no julgamento do processo de impeachment}

Como dito anteriormente, o processo de impeachment tem natureza política: os crimes são políticos, tutelam bens políticos, suas sanções são políticas. De modo que parece lógico que o tribunal responsável por seu julgamento também o seja (BROSSARD, 1992, p. 75).

$\mathrm{O}$ instrumento não atinge o sujeito ocupante do cargo, mas apenas a autoridade nele investida. Isso porque o objetivo do julgamento não é punir o sujeito, mas proteger os interesses públicos contra o abuso do poder oficial, negligência ou conduta incompatível com o exercício do cargo (BROSSARD, 1992, p. 77-78).

Esta distinção fica mais evidente quando se analisa como o Constituinte diferenciou os crimes comuns dos crimes de responsabilidade: nos comuns, o acusado é julgado pelo Supremo Tribunal Federal, conforme determina o artigo 102, inciso I, alínea "b", da Constituição Federal; nos de responsabilidade (políticos), será julgado pelo Senado Federal.

Ademais, a natureza das penas também permite concluir que há diferença entre a 
natureza dos ritos e dos julgamentos: o $§ 3^{\circ}$ do artigo 86 prevê a aplicação de pena privativa de liberdade ao Presidente da República nos crimes comuns, desde que haja condenação prévia, atingindo, portanto, a pessoa do acusado (pena privativa de liberdade). Já o parágrafo único do artigo 52, nos crimes de responsabilidade, limita as penas à perda do cargo e inabilitação por oito anos, atingindo somente a autoridade (BRASIL, 1988).

O Presidente da República é eleito pela maioria absoluta dos votos, em eleições diretas, por sufrágio universal e secreto. É o cargo mais alto do Poder Executivo. Ao Senado cabe julgá-lo, primeiramente, por determinação Constitucional. Assim ocorre em outros países, assim originou-se o instituto na Inglaterra, assim é feito nos Estados Unidos, em cujo modelo inspirou-se o brasileiro. As Constituições brasileiras, desde a imperial, atribuíram às duas Casas do Congresso Nacional a acusação e julgamento do impeachment, ainda que o procedimento tenha sofrido modificações ao longo do tempo.

Por último, cabe ao Senado o julgamento pelo fato de ser um órgão representativo - e é aqui que residirá o principal foco do trabalho. Seguindo a explicação de Paulo Brossard (1992, p. 130-132), em uma redução exemplificativa, a Câmara representaria a totalidade da nação, enquanto o Presidente representaria a parte - na melhor das hipóteses, a maior parte - do eleitorado (BROSSARD, 1992, p. 131). Desta forma, caberia à Câmara, como instituição representativa do povo, acusar o Presidente por condutas incompatíveis com o bom desempenho de suas funções e, ao Senado, processá-lo e julgá-lo.

\section{SOBERANIA, DEMOCRACIA, REPRESENTAÇÃO $\mathbf{E}$ RESPONSABILIDADE}

\section{Conceitos de soberania}

Os conceitos de soberania, democracia e representação estão intrinsecamente ligados. A noção de representação decorre da própria ideia de soberania. Neste trabalho, nos limitaremos a tratar do conceito de soberania ligado à ideia de titularidade do poder político, vinculados às doutrinas democráticas, afastando-nos da discussão a respeito da soberania interna ou externa do Estado, assunto alheio ao debate que se pretende travar aqui.

Fioravanti (2001, p. 72) sustenta que as doutrinas de soberania desenvolveram-se em 
um momento em que o caos político, especialmente na França e na Inglaterra, demandava uma definição a respeito de a quem pertencia a titularidade do poder político.

Jean Bodin (1579, p. 85), ao esboçar uma das mais influentes definições de soberania, a classifica como "um poder absoluto e perpétuo de uma República". Absoluto porque é indivisível, e perpétuo porque é originário, porque não deriva de outro poder. Para Bodin, a titularidade do poder soberano pode manifestar-se de três formas, ou seja, enquadrando-se em um dos seguintes regimes políticos: (i) monárquico, quando o titular do poder é o rei; (ii) aristocrático, quando o titular é um estamento reduzido reunido em assembleia; e (iii) democrático quando o titular é a maioria dos cidadãos.

Independente do regime político assumido por determinada comunidade, este precisará de um governo para dar-lhe suporte. O núcleo deste regime político é rígido, não pode ser alterado pelo governo, e isto porque é neste centro que se manifesta a soberania, onde estão presentes as características fundamentais de uma comunidade política. Desta necessidade de se definir um núcleo inalterável e incorruptível do poder político começa a nascer a concepção moderna de constituição (FIORAVANTI, 2001, 72-77).

Quem definiu com mais precisão o conceito de soberania foi Thomas Hobbes. Sua teoria foi desenvolvida em meio a guerras religiosas na França e conflitos entre monarquia e Parlamento na Inglaterra, disputas que o autor atribuía à constituição mista vigente, que se caracterizava pela divisão do poder para além do monarca em favor de outros sujeitos, como a nobreza e o povo. Hobbes acreditava que essa descentralização do poder provocaria o enfraquecimento do Estado e criaria incertezas quanto à questão da obediência. Neste contexto, a solução proposta por ele seria a concentração do poder nas mãos de um único soberano (LYNCH, 2010, p. 55-56).

Enquanto para Bodin a perpetuidade do poder soberano situa-se no seu caráter originário, não derivado de qualquer outra vontade, e concentrado na pessoa do soberano, seja ele o rei ou uma assembleia de homens, Hobbes segue um raciocínio que seria inimaginável para aquele autor: os indivíduos, em seu estado de natureza, transferem seu direito de autogoverno a um único soberano, sob a condição de que os demais homens também o façam, vale dizer, o poder do soberano decorre da transferência de poder dos indivíduos. Esta transferência se dá por meio da autorização.

Uma vez constituído esse poder soberano comum, manifesta-se o conceito da representação na teoria hobbesiana: os indivíduos, saindo da condição precária em que se encontravam inicialmente, e unidos em torno do poder soberano constituído, deixam de ser 
uma "multidão" e tornam-se um povo. É o fato de serem representados pelo soberano que os transforma em uma unidade reconhecida, em um corpo político (FIORAVANTI, 2001, p. 7981).

A partir de então, em lugar de uma pluralidade de leis fundamentais destinadas a definir os diversos poderes presentes na sociedade e que se encontravam dispersos entre múltiplos segmentos sociais, há uma única lei fundamental, cuja principal função é proteger a integralidade dos poderes soberanos, a fim de manter a ordem pública. Fioravanti conclui, a partir destas premissas, que, se sem soberania não há ordem política, e se a constituição é a condição necessária para um projeto de convivência política pacífica, então sem soberania não há constituição possível (FIORAVANTI, 2001, p. 78-79).

Em Rousseau, a titularidade da soberania deixa de ser do soberano, a quem os indivíduos autorizaram representá-los, e passa a ser dos próprios cidadãos, reunidos em um corpo moral e coletivo, que, por meio do contrato social, "se alienam totalmente com todos os seus direitos a toda a humanidade". Assim, "cada um põe sua pessoa e todo o seu poder sob a suprema direção da vontade geral, e todos recebem cada membro como parte indivisível do todo" (ROUSSEAU, 2003, p. 48, tradução nossa).

Nesta formulação, o soberano é formado por todos os indivíduos contratantes, comprometidos reciprocamente, que se encontram em uma dupla relação: "como membros do soberano, com relação aos particulares, e como membros do Estado, com relação ao soberano" (ROUSSEAU, 2003, p. 50). Desta diferenciação surge a seguinte premissa: os particulares, como parte do todo, devem submissão às leis coletivamente deliberadas, mas o soberano, do qual derivam as leis, não pode criar uma lei que não possa infringir, ou seja, não se submete às próprias leis; não há lei fundamental que vincule o soberano, nem mesmo o próprio contrato social (ROUSSEAU, 2003, p. 50).

O soberano, formado pelos particulares que o compõem, não tem nem pode ter interesses contrários a si próprio; o soberano é formado justamente pelo interesse comum. $\mathrm{O}$ mesmo não ocorre com os cidadãos, individualmente considerados. Nesta condição, podem ter interesses particulares que conflitem com a vontade geral (ROUSSEAU, 2003, p. 51). Daí concluir-se que, para Rousseau, a representação não é possível (PITKIN, 1985, p. 229; FIORAVANTI, 2001, p. 84-85): o que constitui o poder soberano é a vontade geral dos cidadãos, e esta é inalienável e indivisível; a soberania não pode ser representada, a não ser por si mesma (ROUSSEAU, 2003, p. 57).

Rousseau temia que, caso o poder escapasse das mãos do povo soberano, a sociedade 
estaria novamente à mercê dos interesses parciais e das ambições particulares que o contrato social se destinara a regular. Desta forma, não podia conceber a existência de representantes que decidissem em nome dos cidadãos. $\mathrm{O}$ autor diferencia, neste caso, a atuação do poder executivo ("a força") daquela do poder legislativo ("a vontade"). O poder legislativo cabe ao povo, e somente a ele, e corresponde à manifestação de vontade do poder soberano; já o poder executivo é "um corpo intermediário estabelecido entre os súditos e o soberano para sua mútua correspondência, encarregado da execução das leis e da manutenção da liberdade, tanto civil como política" (ROUSSEAU, 2003, p. 88).

Na visão de Darcy Azambuja, o titular do poder político é o povo, por ser ele o elemento humano do Estado, quem põe o Estado em movimento, e o único capaz de vontade e ação. Quanto à titularidade do poder político, portanto, Azambuja conclui ser do povo, quem impulsiona, de certa forma, a criação e a ação do Estado, cabendo a este o exercício do poder político, por ser ele a expressão jurídica da nação organizada (AZAMBUJA, 2008, p. 107108).

\section{Conceitos de representação e projeto democrático}

Nem Hobbes nem Rousseau relacionam representação com democracia, liberdade, autogoverno ou interesse público: o soberano de Hobbes é um representante, sim, em favor do qual os cidadãos alienam seu poder e força para a constituição de um Estado e que atua em defesa do interesse de todos, mantendo assim a paz social. Não obstante, não responde pelos interesses dos súditos, age segundo o que considera ser bom (PITKIN, 1985, p. 30-31). Já para Rousseau, a ideia de representação é incompatível com a ideia de um poder soberano; enquanto a vontade geral produz soberania, as vontades particulares só podem trazer a tirania (PITKIN, 1985, p. 229-230).

No entanto, para além destas formas de representar, Pitkin propõe definições alternativas. Para a autora, o sentido básico de representação está na ideia de "tornar presente alguma coisa que, apesar de tudo, não está literalmente presente" (PITKIN, 1985, p. 10). Uma coisa ou pessoa pode substituir outra desde que haja semelhança entre representante e representado. Segundo esta concepção, uma legislatura seria representativa, portanto, se houvesse uma correspondência entre ela e os membros da população representada.

Uma concepção que se baseie, por exemplo, na arte de representação, exigirá que haja semelhança descritiva entre o representado e seu responsável, de modo que uma legislatura representativa deverá ser um retrato fiel das características daquela comunidade, deverá 
respeitar proporcionalmente as peculiaridades do grupo pelo qual é responsável. Assim, o que qualificaria o representante seria sua representatividade, o que ele é ou parece ser, e não o que faz. Segundo esta definição, o importante é definir a composição da legislatura, e não a função dos representantes (PITKIN, 1985, p. 65).

Outra forma de se representar algo ausente, consoante expõe a autora, é através de um símbolo, que, embora substitua aquilo que representa, não se assemelha àquilo que substitui. Não é uma fonte de informação sobre o que representa, é "o receptáculo de ações ou o objeto de sentimentos que, na verdade, não lhe são destinados, mas àquilo que ele simboliza" (PITKIN, 1985, p. 101). No campo da representação política, esta teoria se verifica na atividade de líderes carismáticos, por exemplo, ou naqueles que despertam reações irracionais ou afetivas nas pessoas; o representante agrada os representados, e é da lealdade ou da crença que surge o vínculo entre ambos. Esta teoria pode facilmente transformar-se de um modelo democrático em um modelo fascista de representação quando o líder usa a influência sobre os cidadãos para convencê-los a querer o que ele quer, a apoiar sua vontade como se fosse deles (PITKIN, 1985, p. 117-118).

Ainda outra forma de representar leva em conta não a substituição de algo ausente, mas uma forma de agir, ou ainda, um agir por outros (PITKIN, 1985, p. 124). A questão central é definir qual, exatamente, é o papel do representante, e os teóricos usam uma variedade de expressões e analogias para explicá-lo: o representante age em favor, em lugar ou em nome de outros, em seu benefício ou interesse, segundo suas reivindicações ou vontades, buscando atender suas necessidades, agradá-los ou satisfazê-los, fazendo o que os próprios representados teriam feito (PITKIN, 1985, p. 125). O representante seria, então, como um ator, um agente, um embaixador, um comissário ou delegado, um deputado, um emissário, um tutor, um fideicomissário, um substituto, um servidor, um solicitador, um guardião, um lugar-tenente.

Pitkin sustenta haver uma polarização entre esses termos, ao que chama de controvérsia "mandato-independência", que pode ser resumida pelo enunciado "deve o representante fazer o que os eleitores querem ou o que ele acha que é melhor? ". Os adeptos da representação como mandato defendem que as ações do representante devem ter relação real com as necessidades dos representados. Por outro lado, os adeptos da representação como independência argumentam que, a menos que o representante tenha autonomia suficiente para agir por si próprio, não se pode falar em representação (PITKIN, 1985, p. 159).

A teoria sustentada por Nadia Urbinati (2006, p. 193), que servirá de marco teórico para o desenvolvimento do tópico 3, retoma os fundamentos defendidos por teóricos da 
democracia representativa no século dezoito, Paine e Condorcet, que viam a representação não como delegação de soberania, mas como processo político conectando sociedade e instituições, e que envolvia tanto representantes quanto cidadãos.

Renegando a concepção moderna de soberania, segundo a qual liberdade política pressupõe monopólio da vontade, Urbinati propõe uma definição de política entendida como "arena de opiniões contestáveis e decisões sujeitas a revisão a qualquer tempo" (URBINATI, 2006, p. 193), na qual a presença política, mais do que o simples ato de votar, acontece também pela manifestação dos cidadãos a respeito das decisões políticas tomadas pelos representantes, e também pelo juízo a respeito da justiça ou injustiça das leis formuladas por eles.

A representação, assim, não é entendida como o simples ato de eleger representantes, embora esta seja uma etapa importante do processo de determinação dos limites e responsabilidades do poder político, mas também como participação política constante. Os cidadãos são chamados a participar do processo democrático, e o fazem ciclicamente, pelo processo eleitoral, ratificando ou recapitulando os atos e promessas dos representantes, marcando o vínculo "entre o lado de dentro e o lado de fora das instituições legislativas", de forma circular (URBINATI, 2006, p. 194 e 201).

Desta forma, a representação, para Urbinati, é uma práxis política que não se resume “à realização arbitrária de escolhas, nem meramente [ao] resultado da barganha entre ambições privadas" (URBINATI, 2006, p. 216). Ela envolve a compreensão, por parte dos participantes, do seu papel na tomada de decisões, na definição do rumo político que pretendem dar ao país (URBINATI, 2006, p. 217; URBINATI, 2013, p. 450). Neste contexto, o aspecto mais importante de um governo representativo é sua capacidade de encontrar soluções para as demandas conflitantes das partes, tendo em vista seu interesse comum no bem-estar geral.

É em torno destas demandas conflitantes que se formam os partidos (URBINATI, 2006, p. 218). A partir da convergência ou divergência de interesses e crenças, cidadãos e representantes podem se reconhecer reciprocamente e identificar adversários, formar alianças e situar-se ideologicamente, a fim de estabelecer estratégias para influenciar as decisões políticas. E para ter influência, é necessário conquistar uma maioridade numérica. Para isso, as opiniões e interesses precisam ser traduzidos em uma linguagem política que seja inclusiva o bastante para absorver uma gama maior de opiniões e interesses (URBINATI, 2006, p. 219).

John Rawls descreve essa estratégia como um "consenso sobreposto", que é a necessidade de os grupos políticos afastarem-se de seu círculo mais restrito de opiniões e 
encontrarem meios de justificá-las para um público mais amplo, a fim de reunir ao seu redor uma maioria (RAWLS, 1987, p. 7-8; URBINATI, 2006, p. 217). Este é, afinal, o objetivo principal de um partido político: "integração da multidão".

Por isso, os partidos políticos são, sem dúvida, um dos mais importantes órgãos de expressão da opinião pública nas democracias representativas. Agregam opiniões e interesses políticos semelhantes, estimulam o engajamento e a participação política dos cidadãos e o embate democrático de ideias. Além de permitir que cada indivíduo, pelos diversos meios de comunicação e informação atualmente disponíveis, verifique e controle a atuação e as posições adotadas pelo seu partido (AZAMBUJA, 2008, p. 319-320).

A representação se dá exatamente pela reunião de opiniões e interesses particulares em torno de um espectro mais amplo de opiniões e interesses, representado pelos partidos políticos. Como se vê, representação e participação não são excludentes. Ao eleger representantes, os cidadãos não estão abrindo mão da participação política ou de sua soberania. Se as eleições fossem voltadas à seleção de candidatos individuais e não de grupos políticos, “o arranjo legislativo seria uma agregação de vontades individuais (...) incapaz de tomar decisões por meio de um processo deliberativo estendido - e, ao final, não-representativo", pois apenas ideias e opiniões em sentido amplo podem ser representados na arena política (URBINATI, 2006, p. 223).

Por isso a representação política depende não apenas de procedimentos eleitorais que permitam aos cidadãos eleger representantes, mas também de autonomia local e liberdade de associação e expressão para que possam influenciar o processo deliberativo, e de igualdade básica de condições para que todos os cidadãos tenham a oportunidade de participar do processo político e ver suas opiniões e interesses representados (URBINATI, 2006, p. 224).

Essa noção de representação vai ao encontro da concepção de democracia procedimental adotada por Saffon e Urbinati (2013, p. 442). As autoras sustentam que a igual participação democrática é o bem mais importante a ser perseguido pela democracia, e a melhor forma de alcançá-lo é seguindo um procedimento democrático moderno, segundo o qual todo indivíduo deve poder participar em eleições justas e competitivas pela escolha de representantes políticos, contribuindo assim para a produção de leis democráticas (SAFFON; URBINATI, 2013, p. 442).

A democracia procedimental, consoante defendido pelas autoras, consiste no respeito à liberdade política; é uma concepção minimalista, pois não exige nada além disso (SAFFON; URBINATI, 2013, p. 445). Igual participação democrática implica não apenas no direito de 
participar na política por meio das eleições e livre expressão de pensamento, mas iguais condições e oportunidades para fazê-lo de forma significativa, o que requer a proteção de direitos sociais, civis e políticos (SAFFON; URBINATI, 2013, p. 442). Neste mesmo sentido, uma democracia só é capaz de proteger a liberdade política igual se os procedimentos pelos quais ela é regulada forem obedecidos.

O objetivo primordial da democracia é e sempre foi garantir a participação de todos no processo político, independente de competência ou posição social, permitindo que os cidadãos criem as leis às quais se submeterão. Não se trata de tomar decisões corretas. Se assim fosse, a participação deveria ser limitada aos sábios e aos especialistas, algo que contradiz a própria ideia de democracia. A democracia é um processo permanente de emenda, de tomada de novas decisões e revisão de decisões anteriores, e essas decisões só serão democráticas se respeitarem as regras de procedimento, ou seja, se garantirem a igual participação política. Na acepção de Saffon e Urbinati, "essas regras protegem a liberdade de produzir decisões moralmente erradas" (2013, p. 448).

Robert Dahl nos apresenta um conceito muito adequado de democracia, coerente com as premissas aqui defendidas: um governo democrático deve ser continuamente responsivo às preferências de seu povo, considerados como politicamente iguais (DAHL, 2005, p. 25-26). Para que isso seja possível, o autor elenca três elementos essenciais: que todos os cidadãos tenham oportunidades plenas de formular suas preferências, de expressá-las a seus concidadãos e governantes através de ações individuais e coletivas, e de que elas sejam igualmente consideradas nas decisões do governo, sem discriminações.

Além disso, Dahl propõe uma noção de democracia formada a partir de duas dimensões: contestação pública e direito de participação. A primeira é necessária justamente para que a segunda seja possível: sem oposição, não pode haver um direito de participação pleno, e para que se atinja um grau de democratização elevado, é preciso que a oposição se dê de forma tolerante e que a participação política seja efetiva (DAHL, 2005, p. 28-31).

A democracia, assim, é melhor do que qualquer outra forma de governo não porque produza boas decisões, mas porque permite que os cidadãos se sintam responsáveis pelas decisões que tomam (SAFFON; URBINATI, 2013, p. 450), que as decisões tomadas pelos representantes reflitam, de fato, os interesses e opiniões dos representados.

Isto, contudo, não significa que qualquer decisão tomada pela maioria seja democrática. Conforme exposto pelas autoras, a democracia procedimental não é ilimitada, se sujeita a balizas constitucionais. O constitucionalismo, afinal, impede que a democracia viole 
direitos garantidos, prevenindo a produção de leis e decisões “incorretas". O constitucionalismo corresponde, enfim, ao único parâmetro ao qual a democracia se sujeita (SAFFON; URBINATI, 2013, p. 448-449).

Além disso, Urbinati destaca a necessidade de se estabelecer um sistema democrático proporcional, e não majoritário. Isto porque o primeiro salvaguarda com mais eficiência os princípios democráticos de igual oportunidade política e controle porque evita a associação enganosa entre "direito de representação" e "direito de decisão" a que o sistema majoritário induz. Embora a maioria detenha o direito ao segundo, não se pode privar a minoria do primeiro (URBINATI, 2000, p. 761).

A democracia é um “"conflito delimitado' ou um 'conflito sem assassinato': não é consenso". O único consenso exigido é em relação às regras e princípios que garantem que, independente do resultado das eleições, os adversários políticos não pegarão em armas, que o resultado será aceito pacificamente por todos (URBINATI, 2006, p. 215-216), e que o conflito se dará apenas mediante o embate de ideias e opiniões.

Para Urbinati, representação e participação são formas relacionadas de ação política que produzem um processo contínuo de tomada de decisões e formação de opiniões (URBINATI, 2004, p. 53). Em uma democracia, embora se permita certa distinção entre representantes e representados, o princípio da igualdade e da identidade do corpo político não podem ser violados; o povo é livre e igual enquanto não existirem instituições intermediárias separando suas vontades e suas decisões (URBINATI, 2004, p. 53-54).

Em suma, a democracia representativa, associada à ideia de democracia procedimental, oferece uma resposta ao problema da soberania: ao possibilitar a participação política dos cidadãos no processo de tomada de decisões e de revisão política, não reduzindo a ação política individual apenas ao momento do voto, é possível conceber uma noção de soberania que não se dissolve pela representação, como acreditava Rousseau, nem é transferida para outro soberano, mas é exercida continuamente e influencia concretamente o resultado do processo político.

Neste sentido, o processo eleitoral significa não apenas um modo de comunicar preferências a um representante, mas é um modo de participar ativamente na esfera pública de deliberação política. Organizando-se em torno de interesses e opiniões comuns, embora nem sempre idênticos ou semelhantes, representados principalmente por partidos políticos, os indivíduos podem definir projetos e acompanhar a atividade legislativa, posteriormente avaliando o desempenho e a representatividade dos eleitos e reiniciando o ciclo. Em suma, um projeto democrático representativo é possível, desde que se garanta igual liberdade política e se 
obedeça às regras do jogo democrático.

\section{Representantes e representados}

É indispensável analisar as formas como os representados elegem e avaliam a atuação dos representantes, uma vez que é neste momento que se verifica se existe ou não representatividade.

Se adotarmos o conceito de Urbinati sobre representação, temos uma prática política de participação na tomada de decisões. Embora constitua uma forma indireta de participação, nem por isso deixa de ser desejável e positiva (URBINATI, 2000, 760). Indireta porque se dá principalmente por meio de grupos políticos e representantes, mas participativa porque permite que os cidadãos influenciem o processo deliberativo e legislativo.

O processo de influência política ocorre basicamente pela eleição de grupos políticos e representantes que prometam defender melhor os interesses de determinado grupo de indivíduos e que então passarão a estar do lado de dentro das instituições legislativas. A partir deste momento, as ações realizadas pelos representantes, suas escolhas e sua atividade legislativa serão avaliadas pelos representados, bem como pela oposição política e pela minoria derrotada no processo eleitoral, e, conforme se decida se foi ou não representativo, o resultado dessa avaliação se refletirá nas próximas eleições.

Mas como se avalia a representatividade de um representante?

Urbinati argumenta que o povo soberano conserva dois poderes: um positivo e um negativo. $\mathrm{O}$ poder positivo consiste, principalmente, no sufrágio. $\mathrm{O}$ poder negativo, por outro lado, compreende a capacidade de investigação, julgamento, influência e reprovação que seu titular exerce sobre seus legisladores, e é negativo por duas razões: (i) tem a finalidade de deter ou mudar determinado curso de ação tomado pelos representantes eleitos e (ii) pode manifestar-se tanto por canais diretos de participação autorizada, como eleições antecipadas, referendos, recall, quanto por canais indiretos ou informais de participação influente, como fóruns, movimentos sociais, associações civis, mídia, manifestações populares (URBINATI, 2006, p. 208-209).

Neste mesmo sentido, ainda que de certa forma sustentando uma opinião mais negativa em relação à efetividade do sistema representativo de modo geral, Azambuja retoma o posicionamento de Rui Barbosa, exposto no Habeas Corpus n 3.536/1914 (BARBOSA, 1989, p. 19), para destacar o papel da imprensa na prestação e na tomada de contas. Esta fiscalização, ainda que meramente moral, sem um poder sancionatório de fato, mas somada ao desejo de 
reeleição do representante, evitaria que este agisse em oposição à vontade do seu eleitorado (AZAMBUJA, 2008, p. 305).

Segundo Young, um importante indício de que há representação é a autorização: "[u]ma pessoa que representa outras de forma oficialmente institucionalizada precisa estar autorizada a falar por elas e, talvez, a uni-las”, o que costuma acontecer mediante eleições regulares (YOUNG, 2006, p. 152).

A autora destaca ainda a vantagem de democracias representativas face às democracias diretas: nestas, do universo de pessoas presentes a uma determinada assembleia, somente algumas se manifestarão e tomarão uma postura ativa no processo deliberativo; as demais permanecerão passivas, aguardando que os demais falem, e depois ponderarão e votarão. Já nas democracias representativas, tendo em vista a presença de institutos de representação formal, é mais provável que haja regras públicas quanto a quem está autorizado a falar por quem, além de normas de responsabilização (accountability) (YOUNG, 2006, 145; URBINATI, 2000, p. 762).

Retomando o raciocínio iniciado anteriormente, é importante lembrar que a democracia representativa conta com grupos e partidos políticos que "integram multidões", reunindo em torno de um "interesse universal” (URBINATI, 2006, p. 218) vários interesses periféricos semelhantes ou próximos. Assim, não se pode esperar que os representantes falem como os eleitos falariam, mas apenas que falem por eles. É necessário reconhecer que há uma diferença entre representante e representado (YOUNG, 2006, p. 149).

A dicotomia "mandato-independência" abordado anteriormente pode ser solucionado entendendo o representante não apenas como um "delegado", que age somente conforme ordenado pelos eleitores, nem como um "fiduciário", que toma decisões independentes sobre a melhor postura a ser adotada, mas alguém cuja função específica "consiste em fazer avaliações independentes, sabendo e antecipando o que os eleitores desejam" (YOUNG, 2006, p. 150). Esta relação entre eleitores e representantes está sujeita a separações, sempre que as avaliações do representante sobre os desejos dos eleitores forem incorretas, ou a conexões, mantidas ao longo do tempo mediante antecipações e retomadas em momentos de autorização (eleições) e prestação de contas (YOUNG, 2006, p. 153).

Assim, Young continua, o representante deve, ao longo do seu mandato e das deliberações que realiza em conjunto com os demais representantes, retomar as discussões realizadas no momento de sua autorização (onde se estabeleceram as estratégias e objetivos do seu mandato, os interesses a serem defendidos, posições políticas, etc.) e antecipar o momento 
da prestação de contas a fim de ponderar os prováveis desejos dos seus representados diante de determinada matéria posta em discussão e sobre a qual deva se posicionar (YOUNG, 2006, p. 154). Mas a avaliação sobre a conformidade ou não de suas escolhas diante da autorização que lhe foi dada só acontecerá posteriormente, e é este momento que o representante deve antecipar.

No momento de prestação de contas, os representados, constituindo uma base eleitoral, debaterão sobre a adequação ou não das decisões do representante, processo este semelhante ao processo de autorização, mas enriquecido com novas informações adquiridas ao longo do mandato e das quais não dispunham antes, no momento da autorização. Neste momento, o representante buscará não apenas provar que seu mandato correspondeu às expectativas depositadas sobre ele, mas também que as suas avaliações foram adequadas.

Este momento de prestação de contas costuma ser mais fraco que o de autorização, e a reautorização costuma resumir-se à reeleição, o que não se coaduna com a noção de uma democracia comunicativa. Para isso, seria necessário que houvesse outros instrumentos de convocação dos representantes e de prestação de contas para além do momento de reautorização, como, por exemplo, associações civis, fóruns, conselhos de supervisão, comissões de estudos de implementação, e audiências participativas periódicas, etc. Estas alternativas permitem aprofundar o processo de responsabilização, possibilitando críticas, elogios, questionamentos, ou seja, uma comunicação mais eficiente entre os atores políticos (YOUNG, 2006, p. 155).

Este processo de avaliação tem uma perspectiva antecipatória e outra retrospectiva: no momento da autorização, os eleitores fazem uma avaliação antecipatória, criando expectativas quanto às decisões que serão tomadas pelo representante, com base nas promessas feitas e das discussões prévias. No momento da reautorização, a avaliação é tanto retrospectiva, mediante análise das decisões tomadas no mandato anterior e comparação delas com as expectativas criadas quando da autorização, quanto antecipatórias, na medida em que novas previsões e expectativas serão criadas, e novos acordos e promessas serão feitos.

Em suma, em uma democracia representativa, a participação ativa dos cidadãos é necessária em todas as etapas, tanto no momento prévio à autorização - o momento deliberativo em que os eleitores e candidatos definem interesses a serem defendidos -, quanto no momento de autorização - ao eleger os representantes com as melhores propostas ou que prometem defender determinados interesses -, e finalmente durante a prestação de contas, ao avaliar o desempenho e as decisões tomadas pelos representantes (AZAMBUJA, 2008, p. 322). 
Este processo, quando segue as regras do jogo e respeita os princípios pelos quais se pauta o processo democrático, garante que a representação seja, de fato, uma ferramenta de exercício de soberania e de tomada democrática de decisões, e não um instrumento de defesa de interesses particulares ou tirânicos, alvo das primeiras teorias democráticas e de soberania popular.

\section{Constitucionalismo, separação de poderes e responsabilidade do poder executivo}

Voltemos à discussão anterior, a respeito das concepções de soberania. O contexto em que se desenvolvem as teorias de Hobbes e Rousseau, consoante sustentado anteriormente, justificavam, ou mais bem exigiam, um poder soberano indivisível e absoluto, derivado da vontade dos próprios indivíduos. Era um conceito necessário em um contexto de instabilidade política no qual ainda não haviam tomado forma os direitos individuais, e que permitiu o surgimento de uma ideia de constituição moderna, mas era incompatível com duas características inerentes ao constitucionalismo moderno: a separação do poder soberano e sua limitação por uma norma fundamental (FIORAVANTI, 2001, p. 85-86).

Com a queda da monarquia, da constituição mista medieval e com o nascimento da República, em 1649, na Inglaterra, têm origem outras teorias sobre o constitucionalismo moderno, fundamentadas na ideia de uma ordem constitucional equilibrada e contrapesada que tornasse possível uma relação estável entre os cidadãos e os poderes públicos. Distingue-se, assim, constituição mista, ultrapassada pelos acontecimentos, de governo misto, limitado por direitos individuais e pelo contrapeso dos poderes.

John Locke é o primeiro a idealizar uma forma de governo equilibrada e moderada, dividido entre o legislador e uma lei comum que estabelecesse uma "medida comum" para a solução das controvérsias, um juiz imparcial para aplicar a lei, e um outro poder, o executivo, com a força necessária para fazer cumprir as decisões do judiciário (FIORAVANTI, p. 91-92).

Desta concepção decorre que o Poder Legislativo, ainda que considerado "supremo" em várias ocasiões pelo próprio autor, é um poder limitado, que não surge para criar direitos, mas para aperfeiçoar sua tutela, pressupondo-se sua preexistência. Assim, não poderá dispor arbitrariamente sobre a vida e os bens dos cidadãos, devendo agir segundo leis promulgadas e juízes autorizados e reconhecidos (FIORAVANTI, p. 91-92). Em suma, e daí deriva o primeiro pressuposto do constitucionalismo, quem detém o poder de fazer as leis não pode dispor 
também dos meios e recursos para governar, nem deter os meios de coação dos indivíduos.

Montesquieu segue a mesma linha de Locke, propondo limites entre os poderes, atribuindo ao Executivo um poder de veto sobre as leis elaboradas pelo Legislativo, de modo a evitar a absorção daquele por este, em um sistema de freios que tem a finalidade de limitação recíproca, e não de coparticipação, o que configuraria usurpação da competência de um poder por outro.

No século XVIII, as teorias constitucionalistas começaram a ser contrapostas à ideia de soberania popular e vontade direta do povo, principalmente depois das críticas de Jeremy Bentham e da publicação do Contrato Social, por Rousseau. Para Bentham, a verdadeira diferença entre um governo livre e uma tirania não estava no limite entre os poderes, mas no modo de participação do poder legislativo pelas diferentes classes, pela responsabilidade dos governantes diante dos governados, e pelo modo de organização das liberdades políticas, como imprensa e associação. Em resumo, quando o poder fosse autenticamente legitimado pelo consenso popular, quando fosse controlado pelo povo e responsável diante dele, não seria necessário insistir na imposição de limites e na existência de uma constituição (FIORAVANTI, 2001, p. 101-102).

A Constituição inaugurada pelos americanos se pretendia democrática em seu fundamento e republicana em sua forma de limitação dos poderes, em oposição à tradicional constituição mista inglesa, que consideravam uma nova forma de absolutismo. Para isso, recuperaram da tradição inglesa as técnicas de equilíbrio e limitação dos poderes a fim de constituir um governo limitado, de poderes limitados porque derivados do poder constituinte originário (FIORAVANTI, 2001, p. 106-107). Este aspecto republicano estava presente nos mecanismos utilizados para limitar os poderes: bicameralismo, poder de veto do Presidente, necessário consenso do Senado para o exercício de certos poderes presidenciais.

Neste cenário, Kant negava a existência de uma ação legítima de resistência por parte do povo em relação ao poder de coação do Poder Executivo. Para ele, havia uma afronta ao princípio fundamental da separação dos poderes, pois o povo - que no modelo ideal de constituição republicana era chamado apenas para eleger seus representantes, aí entendidos os legisladores -, desta forma, pretenderia coagir o Executivo a agir de determinado modo, o que resultaria em um poder despótico, concentrado (KANT, 1917, p. 125-128; FIORAVANTI, 2001, p. 126). Daí a necessidade de negar ao povo a oposição direta ao Poder Executivo, para afirmar-se outro aspecto da constituição republicana, a saber, seu caráter representativo: somente o Legislativo, nunca o povo diretamente, pode vigiar a atuação do governo e sua 
observância às leis, a fim de se respeitar a separação entre os poderes. Se analisarmos a postura de Kant sob o enfoque das teorias representativas vistas anteriormente, será possível entender melhor a organização política do Estado e as formas como se dá a responsabilização dos representantes e governantes.

O Poder Legislativo é composto de representantes do povo e dos Estados federados, eleitos por voto direto. Suas funções incluem tanto a edição de atos normativos quanto a fiscalização das atividades da Administração Pública (MENDES, p. 2012, p. 911-933). Quando exerce aquela função, atua no interesse dos seus representados, pautando-se pelas normas constitucionais de edição de leis e pelos princípios que regem o processo democrático de participação política, prestando conta de suas escolhas políticas perante os eleitores, de acordo com o que foi demonstrado anteriormente. Por outro lado, quando exerce função fiscalizatória, também age no interesse dos seus representados, no entanto, quem presta contas neste caso é o Poder Executivo.

Este processo de prestação de contas e responsabilidade se dá por meio do poder de fiscalização do Poder Legislativo, mas também pelo processo de responsabilidade, nos casos mais graves de má conduta no exercício das funções inerentes ao cargo e pela prática de atos que importem ofensa à Constituição. Quanto a isso, muito se disse no primeiro tópico, perpassando tanto os crimes considerados políticos quanto a forma como se dá o julgamento.

Em suma, o processo de responsabilidade do Chefe do Executivo é competência do Poder Legislativo exatamente por seu caráter representativo e democrático. Mas como conceber, então, a existência, na própria Constituição Federal, de "representantes" não representativos, que praticam todos os atos inerentes à atividade parlamentar, mas não se submetem ao processo democrático de representação?

\section{OS SUPLENTES NO SENADO FEDERAL}

A Constituição do Império de 1824, embora já estabelecesse a organização do Senado Federal, não fazia alusão ao cargo de suplente parlamentar. Os cargos deixados pelos Senadores titulares eram preenchidos mediante novas eleições nas respectivas províncias, uma vez que as eleições para senador eram provinciais.

Enquanto na Constituição do Império (BRASIL, 1824) era permitido que o senador fosse nomeado para o cargo de Ministro de Estado ou Conselheiro de Estado e mantivesse o assento no Senado, a Constituição de 1891 impunha a perda do mandato em tais casos e previa a convocação de novas eleições, nas quais o senador afastado não podia concorrer (artigos 31, 
parágrafo único, e 50, parágrafo único).

O cargo de suplente só teve previsão constitucional em 1934, embora a Lei Maior da época nada diga sobre a suplência senatorial, referindo-se somente ao cargo de suplente de deputado federal, nos artigos 35 e 62 (BRASIL, 1934). A Constituição seguinte, de 1937, voltou a abolir a suplência e estabeleceu a convocação de eleições suplementares para o preenchimento das posições vagas (artigo $39, \S 3^{\circ}$ ).

A Carta de 1946, nos artigos 52 e $60, \S 4^{\circ}$, voltou a permitir a existência dos suplentes, que seriam eleitos com o senador, e ocupariam a vaga em caso de nomeação do titular para cargos de Estado ou em caso de licença (BRASIL, 1946).

A Constituição de 1967 repetiu os preceitos da anterior, e a Emenda Constitucional $n^{\circ}$ 8, de 1977, aumentou para dois o número de suplentes por senador, bem como incluiu os "cargos biônicos", aos quais se ascendia, não mediante submissão ao sufrágio popular, mas "pelo sufrágio do colégio eleitoral" constituído nos mesmos termos daquele destinado à eleição dos governadores na época (artigos $13, \S 2^{\circ}$, e $41, \S 2^{\circ}$, da $\mathrm{EC} \mathrm{n}^{\circ} 8 / 77$ ).

Atualmente, a Constituição Federal adota o mesmo número de suplentes da Carta anterior: "cada senador será eleito com dois suplentes" (BRASIL, 1988, artigo $46 \S 3^{\circ}$ ), que ocuparão o cargo nas hipóteses de nomeação do titular para outras funções de Estado, licença médica, renúncia, perda do mandato ou falecimento, nos termos dos artigos $4^{\circ}, \S 6^{\circ}, 28$ e 45 do Regimento Interno do Senado Federal e 56, § $1^{\circ}$, da Constituição de 1988. Ao suplente em exercício é devida a remuneração de senador a partir da posse, conforme o artigo 12 do Regimento Interno do Senado. O artigo 56, § 2º da Constituição Federal de 1988 ainda estabelece que, "ocorrendo vaga e não havendo suplente, far-se-á eleição para preenchê-la se faltarem mais de quinze meses para o término do mandato".

Quanto às funções, o suplente assume integralmente o cargo do senador ausente. $\mathrm{O}$ $\operatorname{artigo} 4^{\circ}, \S 6^{\circ}$, do Regimento Interno do Senado Federal dispõe que, findo o prazo de noventa dias, se o senador eleito não tomar posse, será considerada sua renúncia e convocar-se-á o primeiro suplente, que será então investido no cargo.

Sobre as prerrogativas, imunidades e incompatibilidades, o Supremo Tribunal Federal já se manifestou no sentido de que, enquanto suplente, inativo, não exercendo as funções parlamentares, o suplente não goza das garantias conferidas ao titular do mandato, somente vindo a adquirir prerrogativas de foro, imunidades e incompatibilidades ao ser investido no cargo, conforme verificado nos Inquéritos $\mathrm{n}^{\mathrm{o}} 1.244, \mathrm{n}^{\circ} 1.537, \mathrm{n}^{\circ} 1.659$ e $\mathrm{n}^{\circ} 1.684$.

O Relatório da Presidência do Senado Federal, referente à $4^{\mathrm{a}}$ Sessão Legislativa da $54^{\mathrm{a}}$ 
Legislatura (BRASIL, 2014d), informa que, ao longo de todo o ano de 2014, 27 (vinte e sete) suplentes foram convocados a assumir o mandato do titular, sendo que 11 (onze) deles permaneceram no cargo por mais de um ano. No ano anterior, 23 (vinte e três) suplentes haviam sido convocados, dos quais 15 (quinze) ocuparam o cargo por um período superior a um ano (BRASIL, 2013a).

Neiva e Izumi trazem alguns dados sobre a suplência no Senado: no período posterior à Constituição de 1988, os suplentes responderam por mais de 16\% dos votos dados no plenário, sendo que, em alguns casos, sua participação aproximou-se de um quarto da composição da Casa (NEIVA; IZUMI, 2012, p. 2). Isto pode ser particularmente preocupante quando consideramos que, apesar de não serem eleitos, os suplentes assumem o cargo do titular com todas as suas funções e prerrogativas, e votam em todas as deliberações como se titulares fossem.

Em relação aos critérios adotados para a nomeação dos suplentes, Neiva e Izumi apontam quatro motivos principais: “(...) a acomodação dos partidos que fazem parte da aliança eleitoral; (...) o [vínculo] afetivo (escolha de parentes); a retribuição aos financiadores de campanha; a mera casualidade; e até mesmo acordo para divisão do mandato" (MORAES, 2006; OLIVEIRA, 2005; PESSANHA \& BACKES, 2007; RUDY, 2004; WEFFORT, 2009 apud NEIVA; IZUMI, 2012, p. 6).

Os critérios obscuros de escolha dos suplentes de senador têm sido criticados pela imprensa há algum tempo. Embora não sejam ilegais, os critérios citados no parágrafo anterior podem ser considerados questionáveis do ponto de vista moral. Embora os eleitores conheçam seus senadores e os escolham pelo grau de afinidade política que despertam no eleitorado, os suplentes não costumam ser conhecidos, e sua condição ou sua relação com o partido é raramente transparente. Embora alguns suplentes cuja relação com o titular é de parentesco sejam conhecidos dos cidadãos, o mesmo dificilmente pode ser dito em relação aos financiadores de campanha.

A prática poderia adquirir algum grau de moralidade se fosse feito abertamente e de forma transparente e pública, de forma a deixar claro aos eleitores a natureza do vínculo entre o suplente e o partido, e principalmente de que forma ele se alinha aos interesses políticos defendidos pelo partido, quais interesses, afinal, serão defendidos pelo suplente caso venha a ser investido na função parlamentar.

\section{Suplência sob o enfoque da democracia representativa}


Embora previsto constitucionalmente, o instituto da suplência levanta algumas questões quanto à sua representatividade. Consoante abordado anteriormente, não se pode conceber uma democracia representativa sem a participação dos cidadãos soberanos no processo político de autorização dos representantes.

O momento de autorização pressupõe o conhecimento prévio dos cidadãos sobre os candidatos concorrentes, haja vista a necessidade de identificação entre os representantes e representados, o que se dá pela informação que aqueles recebem sobre as promessas destes e suas propostas de campanha, conforme elaborado no tópico anterior. Este é um momento essencial do procedimento democrático. É por meio do processo de autorização que os cidadãos reconhecem seus representantes como tal e concordam com que ele ocupe um cargo na estrutura legislativa e tome decisões em seu nome.

O suplente, contudo, não se submete ao processo de autorização. Primeiramente, sua nomeação não decorre de suas posições políticas, ou dos interesses que defenda, e muitas vezes, sequer depende de filiação ao partido: muitos suplentes são empresários que financiaram as campanhas de seus titulares (NEIVA; IZUMI, 2012, p. 7-8). Em suma, o suplente não tem nenhuma relação com os eleitores.

Somado ao fato de que poucas vezes é conhecido dos eleitores e de que raramente aparece junto ao titular ao longo da campanha eleitoral, o suplente não presta contas de suas ações. Por não se submeter a eleições periódicas, não está sujeito à sanção política, que consiste, principalmente, na recusa dos cidadãos em reeleger o político faltoso. Ademais, como a maioria dos suplentes não conta com experiência política anterior, raramente se candidatam na eleição seguinte. Além não terem representatividade, não se sentem obrigados a conquistar a confiança e a simpatia do eleitor (NEIVA; IZUMI, 2012, p. 3).

Embora se possa tentar argumentar que o cargo do suplente se assemelha àquele do vice de prefeito, governador e Presidente da República, que ingressam nas instituições representativas sem receber votos diretos, o argumento não prospera. Diferente destes, os candidatos a vice costumam participar ativamente das campanhas junto com os titulares, sendo dado aos eleitores conhecê-los e julgá-los, afinal tomam posse e exercem o mandato simultaneamente com o titular, têm atribuições e responsabilidades específicas e recebem salários e vantagens próprias do cargo (NEIVA; IZUMI, 2012, p. 5).

Ainda que os suplentes estejam vinculados aos titulares, estes, sim, eleitos diretamente pelo voto popular e sujeitos à accountability e responsividade, não se pode presumir que sejam 
igualmente legitimados a ocupar um cargo eletivo. A representação divide-se em fases voltadas a conferir-lhe legitimidade: é necessário que haja, primeiramente, a etapa de autorização, mediante a qual os eleitores votam diretamente nos candidatos com os quais se identificam, e que, posteriormente, os representantes eleitos prestem contas, submetendo-se a novas eleições, ou participando de fóruns, reuniões partidárias com a base eleitoral, dentre inúmeras formas de accountability apontadas anteriormente.

Destaque-se que o suplente, quando assume o cargo do titular, o faz mediante rito de posse, no qual elege um nome parlamentar e é investido no cargo de senador. A partir deste momento, sua atuação no Senado é feita em seu próprio nome: ele não age "em nome" do titular, votando em nome dele, de maneira a permitir que o eleitor responsabilize o titular pelas ações e escolhas do suplente. Vota como se titular fosse. Como dito anteriormente, o eleitor raramente sabe quem são os suplentes dos senadores no qual votou ${ }^{4}$, de modo que dificilmente avaliará o mandato deles na hora de eleger seus senadores.

O suplente, assim, ingressa no sistema político, em um dos cargos mais prestigiados e influentes do país, "de carona", sem receber um único voto para isso, sem submeter-se aos mecanismos democráticos de representação e sem prestar contas de seus atos. Exerce todos os atos inerentes à função de senador, recebe os vencimentos próprios do cargo, está sujeito às mesmas imunidades e prerrogativas do titular quando está em exercício, sem, contudo, responder perante o cidadão soberano pelas decisões que toma. Seu voto, em sessão, tem o mesmo peso que o voto dos senadores eleitos, inclusive em matérias de grande impacto político, social ou econômico, é considerado para fins de quórum, e pode ser a diferença entre a aprovação ou reprovação de uma proposta de emenda constitucional, ou então entre a condenação ou a absolvição do Presidente da República.

\section{SUPLENCIA E O PROCESSO DE IMPEACHMENT}

Conforme tratado no tópico primeiro, cabe ao Senado Federal julgar o Presidente da República e seu vice pelos crimes de responsabilidade sempre que a Câmara dos Deputados autorizar a instauração do processo e, por dois terços dos votos, condená-los à perda do cargo, podendo também decretar a sua inelegibilidade pelo prazo de oito anos.

Sendo o Senado composto por oitenta e um senadores, três por Estado da federação e

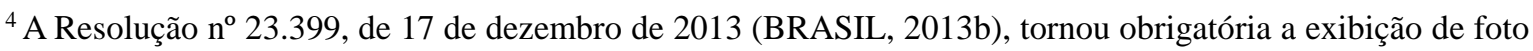
e nome dos respectivos suplentes no painel da urna eletrônica, junto ao nome do senador, conforme dispõe o artigo92, $\S 2^{\circ}$, da referida resolução. Esta norma passou a valer nas eleições de 2014.
} 
pelo Distrito Federal (artigo 46, § 1º da Constituição Federal), serão necessários, no mínimo, cinquenta e quatro votos favoráveis à condenação para que o acusado seja destituído do cargo. Dada a natureza do processo e a relevância da matéria, estabeleceu-se o quórum qualificado de dois terços - o maior quórum exigido no Congresso - tanto para a autorização pela Câmara quanto para a condenação pelo Senado (KLARMAN, 1999, p. 637).

Durante o ano de 2014, como dito anteriormente, um terço da Casa foi substituído por suplentes. Onze deles permaneceram no cargo por mais de um ano. Diante destes dados, percebe-se quão preocupante é o índice de suplência verificado no Senado ao longo de cada legislatura (BRASIL, 2014d). Embora já seja questionável sua representatividade em qualquer deliberação, quer votando em projetos de lei, quer atuando em comissões permanentes, quer deliberando sobre assuntos meramente regimentais, o problema fica mais evidente diante de questões delicadas, que receberam atenção especial do legislador originário.

É questionável a legitimidade do papel ocupado pelo suplente na democracia representativa, e os obstáculos que ele representa no processo democrático. Nesse sentido, merece destaque este trecho da obra de Urbinati:

Em uma democracia, embora se permita certa distinção entre representantes e representados, o princípio da igualdade e da identidade do corpo político não podem ser violados; o povo é livre e igual enquanto não existirem instituições intermediárias separando suas vontades e suas decisões (URBINATI, 2004, p. 53-54; grifo nosso).

A própria existência do instituto da suplência na Constituição brasileira é um contrassenso. Que o constituinte autorize a existência concomitante de legisladores eleitos democraticamente e legisladores nomeados por critérios escusos viola a própria ideia de soberania e representatividade protegidos pela mesma Constituição. Como observado anteriormente, o Brasil já adotou sistemas mais democráticos de substituição parlamentar, como o modelo das Cartas de 1824, 1891 e 1937, que exigiam a convocação de novas eleições para o preenchimento das vagas.

Embora o Tribunal Superior Eleitoral tenha aprovado a Resolução no 23.399/2013 , isso pouco contribuiu para a democratização do instituto. Ainda persistem questões quanto aos critérios de provimento dos cargos de suplente e a extensão dos poderes, dado que não são eleitos diretamente nem têm suas funções e prerrogativas previstas legalmente, como ocorre com os candidatos a vice.

O suplente é um obstáculo ao processo democrático porque ele se interpõe entre o cidadão soberano e a tomada de decisões, cortando o ciclo de representatividade que se dá pelo 
processo eleitoral; ele usurpa a posição do representante eleito, ainda que o faça mediante previsão legal, e passa participar do processo político sem que tenha sido autorizado a isso, sem representar os interesses políticos dos eleitores, e sem responder pelas ações que realiza. Quando levamos essas considerações para o processo de impeachment, o problema torna-se mais grave.

Consoante observado no primeiro tópico, o Presidente, Chefe do Poder Executivo, é o mais alto posto político de uma República presidencialista. Eleito por maioria de votos em eleições democráticas, ele representa os interesses do país, quer internamente, quer internacionalmente. Exigir a sua responsabilização por atos nocivos à Constituição e às instituições do país é medida não apenas necessárias, mas desejada, afinal "governo irresponsável, embora originário de eleição popular, pode ser tudo, menos governo democrático" (PILLA apud BROSSARD, 1992, p. 3).

Não obstante, o cargo de Chefe do Executivo nacional é uma das instituições republicanas que garantem a existência de uma democracia fundada em ideais de soberania, separação de poderes, representatividade, de modo que sua destituição deve obedecer estes mesmos princípios se se pretende legítima.

A existência do instituto do impeachment, como demonstrado à exaustão anteriormente, é uma ferramenta democrática que permite aos cidadãos, representados pelo Poder Legislativo, imputar ao Presidente (ou outros agentes políticos infratores) a responsabilidade por condutas tidas como inapropriadas ou prejudiciais aos negócios do Estado e aos interesses do país, ou que atentam contra a Constituição Federal.

Deste pressuposto decorre a necessidade de que o processo de impeachment respeite as regras do procedimento democrático: que seja iniciado na Câmara dos Deputados, representativa dos interesses de todos os cidadãos, e se encerre no Senado Federal, alçado pelo constituinte originário à posição de órgão julgador, respeitando as normas procedimentais impostas pela lei reguladora do instituto e pelas regras constitucionais aplicáveis.

Estes requisitos visam garantir um julgamento político justo, democrático e representativo, que submeta o Presidente da República ao julgamento de representantes democraticamente eleitos $^{6}$, que são, afinal, os únicos legitimados a destituí-lo do cargo, por

\footnotetext{
${ }^{5}$ Ver nota $\mathrm{n}^{\mathrm{o}} 2$.

${ }^{6}$ A observância das regras de procedimento do impeachment pode ser plenamente submetida ao controle judicial do Supremo Tribunal Federal, mormente quando não assegurado o devido processo legal, a ampla defesa e o contraditório, conforme recentemente observado nos MS 33.838, rel. Min. Rosa Weber, MS 33.387, Rel. Min Teori Zavascki, e Rcl. 22.124, Rel. Min Teori Zavascki.
} 
expressa previsão constitucional e construção interpretativa decorrente da própria história do desenvolvimento do impeachment. Neste contexto, como interpretar a participação de "representantes" não eleitos no processo de julgamento?

Pelo voto de dois terços dos senadores, o Presidente é condenado ou absolvido. A diferença pode ser decidida por um único voto, ou seja, a decisão pode caber a um senador que não recebeu um único voto popular para exercer o cargo, e que, terminado o mandato, não prestará conta das decisões tomadas.

O quadro se agrava quando consideramos que as decisões do Senado não estão sujeitas a recurso ou revisão por outras esferas públicas: seus veredictos são absolutos e irreversíveis (BROSSARD, 1992, p. 149-152). ${ }^{7}$

O impeachment, como processo político, tem como objetivo resguardar o Estado dos efeitos nocivos de um governo negligente e prejudicial aos interesses da nação, e, como as considerações deverão ser igualmente políticas, seu julgamento é submetido ao crivo de um tribunal político, a saber, o Senado Federal.

Brossard reconhece a probabilidade de ocorrer abusos e violências quando se submete um julgamento desta monta a um tribunal composto por representantes políticos com interesses muitas vezes conflitantes, mas destaca a prudência do constituinte em atribuir a acusação à Câmara e o julgamento ao Senado, exigindo o voto de no mínimo dois terços dos membros de cada Casa, tanto para autorizar para instaurar o processo quanto para condenar o acusado (1992, p. 144-148).

Continuando, a própria natureza política do processo indica a necessidade de se resguardar a representatividade política dos julgadores, para que todos sejam verdadeiramente legitimados a analisar, ponderar e votar, segundo os interesses que representam, de modo que o resultado reflita a vontade popular compreendida na postura e nas escolhas dos representantes que compõem o Congresso Nacional.

Desta forma, quando o constituinte repetiu o preceito das Constituições anteriores e permitiu a atuação de um legislador não eleito e irresponsável, no sentido político do termo, terminou por comprometer a própria idoneidade do Senado Federal para proceder a deliberações e julgamentos cujas consequências alcançam toda a sociedade.

Feitas todas estas considerações, verifica-se quão prejudicial à democracia

\footnotetext{
${ }^{7}$ Isto não significa dizer que não haja qualquer controle externo do procedimento. Cabe recurso ou revisão judicial contra os atos praticados no curso do processo de impeachment que violem cláusulas legais ou constitucionais, como ocorre nos processos administrativos. Não são admissíveis, contudo, os recursos voltados a questionar ou reformar o mérito da condenação.
} 
representativa é o instituto do suplente, especialmente quando analisamos a questão à luz do processo de impeachment, provavelmente um dos mais incisivos instrumentos democráticos de responsabilização política. A deposição do ocupante do mais alto cargo Executivo da República pelo voto de legisladores sem nenhuma representatividade seria um grave retrocesso em termos de democracia.

\section{CONCLUSÃO}

Este artigo teve como objetivo verificar em que medida o suplente de senador é legitimado a participar do julgamento político do Presidente da República, tendo em vista as muitas questões relativas à representatividade dos suplentes, a harmonia do instituto da suplência com os ideais de democracia e soberania popular, especialmente diante da relevância e gravidade de um processo de impeachment.

A eleição não se encerra no momento do voto, mas prolonga-se, ininterruptamente, compreendendo tanto o momento prévio à votação quanto o período de fiel cumprimento do mandato concedido ao representante eleito. A representação é um processo político que, para que seja democrático, requer a participação dos eleitores em cada uma de suas fases, desde o momento da autorização até a prestação de contas, que ocorre ao fim de cada mandato.

No Poder Legislativo, os representantes tomarão decisões e participarão de deliberações, constantemente avaliando como seus eleitores interpretarão cada atitude sua e decidindo a melhor maneira de representar seus interesses. É com base nestas escolhas que os representados avaliarão a qualidade do mandato de seus representantes eleitos. $\mathrm{Na}$ fase posterior, de prestação de contas (que pode coincidir, ou não, com as eleições), os eleitores julgarão quão representativos foram seus candidatos, e a partir daí decidirão se renovam a autorização concedida (reeleição) ou se a revogam, negando-lhe o voto nas eleições seguintes.

Percebe-se, neste momento, a existência de alguns requisitos para que a representação seja de fato "representativa" e democrática, a saber, a autorização e a prestação de contas. Sem estes dois elementos, não se pode falar em representação, menos ainda em democracia representativa. As eleições, neste caso, são um indicativo da presença ou não destes elementos.

E é exatamente neste panorama que se pode concluir pela inexistência de representatividade do suplente de senador. Nomeado mediante critérios questionáveis (que incluem relação de parentesco com os titulares, financiamento da campanha, dentre outros, conforme explorados no tópico 3), o suplente chega ao Senado sem, para isso, receber um único voto direto em seu nome. Não há sequer a exigência de que conste da lista dos senadores 
mais votados e que sua indicação se dê por ordem decrescente de votos recebidos, o que, embora possa ser questionável, ainda seria uma forma mais democrática de investidura. E, após o fim do seu "mandato", não presta contas à sociedade pelos atos praticados. Neste sentido, sua atuação no processo de julgamento político do Presidente da República é altamente questionável.

Diante disso, a presença de senadores não eleitos no julgamento do processo de impeachment é uma grave afronta à soberania popular e à democracia. Se não foram autorizados a atuar na esfera legislativa, se não defendem os interesses de eleitores e não prestam contas de suas escolhas políticas, seu voto em um processo como o impeachment somente poderá representar seus próprios interesses individuais. E isto não é admissível em uma democracia.

\title{
IMPEACHMENT AND DEMOCRATIC REPRESENTATION: THE ROLE OF SENATORS' SUBSTITUTE
}

\begin{abstract}
This article aims at establishing analyses in order to identify how the role of Senators' substitute dues with concepts sovereignty democracy and representativeness, mainly because there are not invested in its position by popular and direct vote. Therefore, if they are not invested, how should be understood its participation in the political judgment of the President. Firstly, we will draw a historical approach of the impeachment process in accordance with Brazilian law, outlining Senators' substitute perform the procedure. After, it will be pointed out the relation among sovereignty, representation and democracy from Nadia Urbinati's overview, seeking to clarify how can be comprehended representative's accountability. The third topic addresses the main characteristics of the Senators' substitute by an analysis of the Brazil's legislation, aiming to improve the democratic continent of impeachment process.
\end{abstract}

Keywords: Impeachment; Senators' substitute; Representative democracy; Constitutional Law.

\section{REFERÊNCIAS BIBLIOGRÁFICAS}

ADAMS, George Burton. Magna Carta and the Responsible Ministry. The American Historical Review, vol. 20, n. 4. Julho, 1915, p. 744-760. 
ALMEIDA, D. R. Representação Além das Eleições: Repensando as Fronteiras entre Estado e Sociedade. Jundiaí: Paco Editorial, 2015.

ARGENTINA. Constitución de la Nación Argentina. Disponível em: <http://www.senado.gov.ar/deInteres>. Acesso em: 28 nov. 2015.

AZAMBUJA, Darcy. Teoria Geral do Estado. 4 ed. rev., ampl. atual. São Paulo: Globo, 2008 .

BARBOSA, Rui. Obras completas de Rui Barbosa: Trabalhos jurídicos. Vol. 41, tomo 4. Rio de Janeiro: Fundação Casa de Rui Barbosa, 1989 (original de 1914).

BODIN, Jean. Les six livres de la République. Lyon: Jean de Tournes, 1579.

BOLÍVIA. Constitución política del Estado Plurinacional de Bolivia. Disponível em: <http://www.harmonywithnatureun.org/content/documents/159Bolivia\%20Consitucion.pdf $>$. Acesso em: 28 nov. 2015.

BRASIL (1824). Constituição Política do Império do Brazil: de 25 de março de 1824. Disponível em: <http://www.planalto.gov.br/ccivil_03/Constituicao/Constituicao24.htm>. Acesso em: 10 out. 2015.

BRASIL (1827). Lei de 15 de outubro de 1827. Disponível em: <http://www2.camara.leg.br/legin/fed/lei_sn/1824-1899/lei-38389-15-outubro-1827-566674publicacaooriginal-90212-pl.html >. Acesso em: 10 out. 2015.

BRASIL (1891). Constituição da República dos Estados Unidos do Brasil: de 24 de fevereiro de $1891 . \quad$ Disponível em: <http://www.planalto.gov.br/ccivil_03/Constituicao/Constituicao91.htm>. Acesso em: 10 out. 2015.

BRASIL (1892). Decreto $\mathbf{n}^{\mathbf{0}} \mathbf{3 0}$, de $\mathbf{8}$ de janeiro de 1892. Disponível em: <http://www2.camara.leg.br/legin/fed/decret/1824-1899/decreto-30-8-janeiro-1892-541211publicacaooriginal-44160-pl.html>. Acesso em: 10 out. 2015.

BRASIL (1934). Constituição da República dos Estados Unidos do Brasil: promulgada em 16 de julho de 1934.2 Disponível em: <http://www.planalto.gov.br/ccivil_03/Constituicao/Constituicao34.htm>. Acesso em: 10 out. 2015.

BRASIL (1937). Constituição dos Estados Unidos do Brasil: de 10 de novembro de 1937. Disponível em: <http://www.planalto.gov.br/ccivil_03/Constituicao/Constituicao37.htm>. Acesso em: 10 out. 2015.

BRASIL (1946). Constituição dos Estados Unidos do Brasil: de 18 de setembro de 1946. Disponível em: <http://www.planalto.gov.br/ccivil_03/Constituicao/Constituicao46.htm>. Acesso em: 10 out. 2015.

BRASIL (1950). Lei $\mathbf{n}^{\mathbf{0}}$ 1.079, de 10 de abril de 1950. Disponível em: 
<http://www.planalto.gov.br/ccivil_03/LEIS/L1079.htm>. Acesso em: 28 nov. 2015.

BRASIL (1967). Constituição da República Federativa do Brasil: de 24 de janeiro de 1967. Disponível em: <http://www.planalto.gov.br/ccivil_03/Constituicao/Constituicao67.htm>. Acesso em: 10 out. 2015.

BRASIL (1970). Senado Federal. Resolução $\mathbf{n}^{\mathbf{0}}$ 93, de 1970. Disponível em: <http://www25.senado.leg.br/documents/12427/45868/RISF+2015+Compilado+02.09.pdf/cd5 769c8-46c5-4c8a-9af7-99be436b89c4>. Acesso em: 28 out. 2015.

BRASIL (1977). Emenda Constitucional $\mathbf{n}^{\mathbf{0}}$ 8, de 14 de abril de 1977. Altera artigos da Constituição Federal, incluindo-se em seu Título V os artigos 208, 209 e 210. Disponível em: $<$ http://www.planalto.gov.br/ccivil_03/Constituicao/Emendas/Emc_anterior1988/emc08-

77.htm>. Acesso em: 28 nov. 2015.

BRASIL (1988). Constituição da República Federativa do Brasil: promulgada em 5 de outubro de $1988 . \quad$ Disponível em: <http://www.planalto.gov.br/ccivil_03/Constituicao/Constituicao.htm>. Acesso em: 10 out. 2015.

BRASIL (1989). Câmara dos Deputados. Resolução $\mathbf{n}^{\mathbf{0}}$ 17, de 1989. Disponível em: <http://www2.camara.leg.br/legin/fed/rescad/1989/resolucaodacamaradosdeputados-17-21setembro-1989-320110-normaatualizada-pl.pdf $>$. Acesso em: 28 out. 2015.

BRASIL (2001a). Supremo Tribunal Federal. Suplente de Deputado Federal. Condição político-jurídica que não lhe confere as garantias e as prerrogativas inerentes ao titular do mandato parlamentar. Reconhecimento da falta de competência originária do Supremo Tribunal Federal para o procedimento penal instaurado contra suplente de membro do Congresso Nacional. Decisão monocrática no Inquérito $n^{\circ}$ 1.684/PR. Ministério Público Federal e Moacir Piovesan. Relator: Ministro Celso de Mello, Plenário, DJ de 18.12.2001.

(2001b). Supremo Tribunal Federal. Competência. Ação Penal. Suplente de Deputado Federal. Ausência de exercício do mandato. Decisão monocrática no Inquérito $\mathbf{n}^{\mathbf{0}}$ 1.537/RR. Ministério Público Federal e Elton Rohnelt e Tomaz Emiliano Neto. Relator: Ministro Marco Aurélio, Plenário, DJ de 4.4.2001.

(2001c). Supremo Tribunal Federal. Decisão monocrática no Inquérito $\mathrm{n}^{\mathbf{0}} \mathbf{1 . 6 5 9 / S P}$. Ministério Público Federal e Oswaldo Soler, Ivoni Fuster Corby Soler e Maria Cristina Fuster Soler Bernardo. Relator: Ministro Carlos Velloso, Plenário, DJ de 16.8.2001.

(2001d). Supremo Tribunal Federal. Decisão monocrática no Inquérito no 1.244/PR. Ministério Público Federal e Valdomiro Meger, Antônio Ribeiro Silva, José Braz Guimarães e Humberto Crispim. Relator: Ministro Carlos Velloso, Plenário, DJ de 12.11.2001.

BRASIL (2009). Câmara dos Deputados. Proposta de Emenda Constitucional no 376/2009. Disponível em: <http://www2.camara.leg.br/proposicoesWeb/fichadetramitacao?idProposicao=439075. Acesso em: 28 nov. 2015.

BRASIL (2012). Câmara dos Deputados. Proposta de Emenda Constitucional no 141/2012. Disponível 
<http://www2.camara.leg.br/proposicoesWeb/fichadetramitacao?idProposicao=536156>. Acesso em: 28 nov. 2015.

BRASIL (2013a). Senado Federal. Relatório Anual da Presidência. Disponível em: <http://www25.senado.leg.br/web/atividade/relatorio-anual-da-presidencia/2013>. Acesso em: 28 nov. 2015.

BRASIL (2013b). Tribunal Superior Eleitoral. Resolução no 23.399, de 17 de dezembro de 2013. Disponível em: <http://www.tse.jus.br/eleicoes/eleicoes-anteriores/eleicoes2014/normas-e-documentacoes/resolucao-no-23.399>. Acesso em: 28 nov. 2015.

BRASIL (2014a). Câmara dos Deputados. Proposta de Emenda Constitucional no 379/2014. Disponível em: <http://www.camara.gov.br/proposicoesWeb/fichadetramitacao?idProposicao=606240>. Acesso em: 28 nov. 2015.

BRASIL (2014b). Senado Federal. AURELIANO, Antonio et. al. Proposta de Emenda Constitucional $n^{\circ} 39 / 2014$. Acrescenta o $\S^{\circ}$ ao art. 46 da Constituição Federal, para determinar que os suplentes de Senador sejam eleitos mediante voto direto. Disponível em: <http://www25.senado.leg.br/web/atividade/materias/-/materia/118785>. Acesso em: 28 nov. 2015.

BRASIL (2014c). Senado Federal. Proposta de Emenda Constitucional $\mathbf{n}^{\mathbf{0}}$ 48/2014. Disponível em: <http://www25.senado.leg.br/web/atividade/materias/-/materia/119260>. Acesso em: 28 nov. 2015.

BRASIL (2014d). Senado Federal. Relatório Anual da Presidência. Disponível em: <http://www25.senado.leg.br/web/atividade/relatorio-anual-da-presidencia/2014>. Acesso em: 28 nov. 2015.

BRASIL (2015). Senado Federal. Proposta de Emenda Constitucional no 18/2015. Disponível em: <http://www25.senado.leg.br/web/atividade/materias/-/materia/119902>. Acesso em: 28 nov. 2015.

BROSSARD, Paulo. O impeachment: aspectos da responsabilidade política do Presidente da República. 2. ed. São Paulo: Saraiva, 1992.

DAHL, Robert Alan. Poliarquia: participação e oposição. Tradução de Celso Mauro Paciornik. 1 ed. 1 reimpr. São Paulo: Editora da Universidade de São Paulo, 2005.

DOVI, S. Political Representation, 2014. (Nota técnica).

DWIGHT, Theodore W. Trial by Impeachment. The American Law Register (1852-1891), vol. 15 , n. 5, março, 1867, p. 257-283.

ESTADOS UNIDOS DA AMÉRICA. Constituição (1787). Disponível em: $<$ http://www.senate.gov/artandhistory/history/common/briefing/Direct_Election_Senators.htm $>$. Acesso em: 28 nov. 2015. 
FIORAVANTI, Maurizio. Constitución: de la antigüedad a nuestros días. Tradução de Manuel Martínez Neira. Madrid: Editorial Trotta, 2001.

FRANÇA. Constituição (1958). Constitution de la République Française. Disponível em: <http://www.assemblee-nationale.fr/connaissance/constitution.asp>. Acesso em: 28 nov. 2015.

HOFFER, Peter C. and HULL, Natalie E. H. The First American Impeachments. The William and Mary Quarterly, vol. 35, n. 4, outubro, 1978, p. 653-667.

KANT, Immanuel. Perpetual peace: a philosophical essay. Tradução de Mary Campbell Smith. Londres: George Allen \& Unwit, 1917.

KLARMAN, Michael J. Constitutional fetishism and the Clinton impeachment debate. Virginia Law Review, v. 85, p. 631-1803, 1999.

LAWRENCE, William. The Law of Impeachment. The American Law Register (18521891), vol. 15, n. 11, setembro, 1867, p. 641-680.

LYNCH, Christian Edward Cyril. Entre o Leviatã e o Beemote: soberania, Constituição e a excepcionalidade no debate político dos séculos XVII e XVIII. Revista de Ciências Sociais, Rio de Janeiro, vol. 53, n. 1, 2010, p. 55-90.

MENDES, Gilmar Ferreira; BRANCO, Paulo Gustavo Gonet. Curso de direito constitucional. 7. ed. São Paulo: Saraiva, 2012.

NEIVA, Pedro; IZUMI, Maurício. Os sem-votos do Legislativo brasileiro: quem são os senadores suplentes e quais os seus impactos sobre o processo legislativo. Opinião Pública, Campinas, vol. 1, n. 1, 2012, p. 1-21.

PARAGUAI. Constituição (1992). Constitución Nacional. Disponível em: <http://www.oas.org/juridico/spanish/par_res3.htm>. Acesso em: 28 nov. 2015.

PITKIN, Hannah Fenichel. El concepto de representación. Madrid: Centro de Estudios Constitucionales, 1985.

QUERO, Caio. Congresso deve resistir às sugestões de Dilma para o plebiscito. BBC Brasil. Rio de Janeiro, 2 jul. 2013. Disponível em: <http://bbc.com/portuguese/noticias/2013/07/130702_reforma_politica_cq_lk>. Acesso em: 28 nov. 2015.

RAWLS, John. The Idea of an Overlapping Consensus. Oxford Journal of Legal Studies, Vol. 7, n. 1, 1987, p. 1-25.

ROBERTS, Clayton. The growth of ministerial responsibility to parliament in later Stuart England. The Journal of Modern History, vol. 28, n. 3. Setembro, 1956, p. 215-233.

ROUSSEAU, Jean-Jacques. Contrato social. Tradução de Fernando de los Ríos. Madrid: Espasa Calpe, 2003. 
SAFFON, Maria Paula; URBINATI, Nadia. Procedural democracy: the bulwark of equal liberty. Political Theory, vol. 41, n. 3, 2013, p. 441-481.

SEIDMAN, Guy I. The Origins of Accountability: everything I know about the sovereign immunity, I learned from King Henry III. Saint Louis University Law Journal, vol. 49, n. 2, 2005, p. 1-99.

URBINATI, Nadia. Condorcet's Democratic Theory of Representative Government. European Journal of Political Theory, vol. 3, n. 1, 2004, p. 53-75.

URBINATI, Nadia. Crise e metamorfoses da democracia. Tradução de Pedro Galé e Vinicius de Castro Soares. Revista Brasileira de Ciências Sociais, vol. 28, n. 82, 2013, p. 5-16.

URBINATI, Nadia. O que torna a representação democrática? Lua Nova, n. 67, 2006, p. 191-228.

URBINATI, Nadia. Representation as advocacy: a study of democratic deliberation. Political Theory, vol. 28, n. 6, 2000, p. 758-786.

YOUNG, Iris Marion. Representação política, identidade e minorias. Lua Nova, n. 67, 2006, p. 139-190.

Trabalho enviado em 28 de janeiro de 2016.

Aceito em 23 de março de 2016. 